UCRL-JC- 123970

PREPRINT

CONF- $960401--51$

\title{
A COMPARISON OF THE ELECTROCHEMICAL BEHAVIOR OF CARBON AEROGELS AND ACTIVATED CARBON FIBER CLOTHS
}

\author{
T. D. Tran \\ C. T. Alviso \\ S. S. Hulsey \\ J. K. Nielsen \\ R. W. Pekala
}

This paper was prepared for submittal to the Microporous and Macroporous Materials Symposium of the Spring Meeting of the Materials Research Society

San Francisco, California

April 8-12, 1996

May 10, 1996

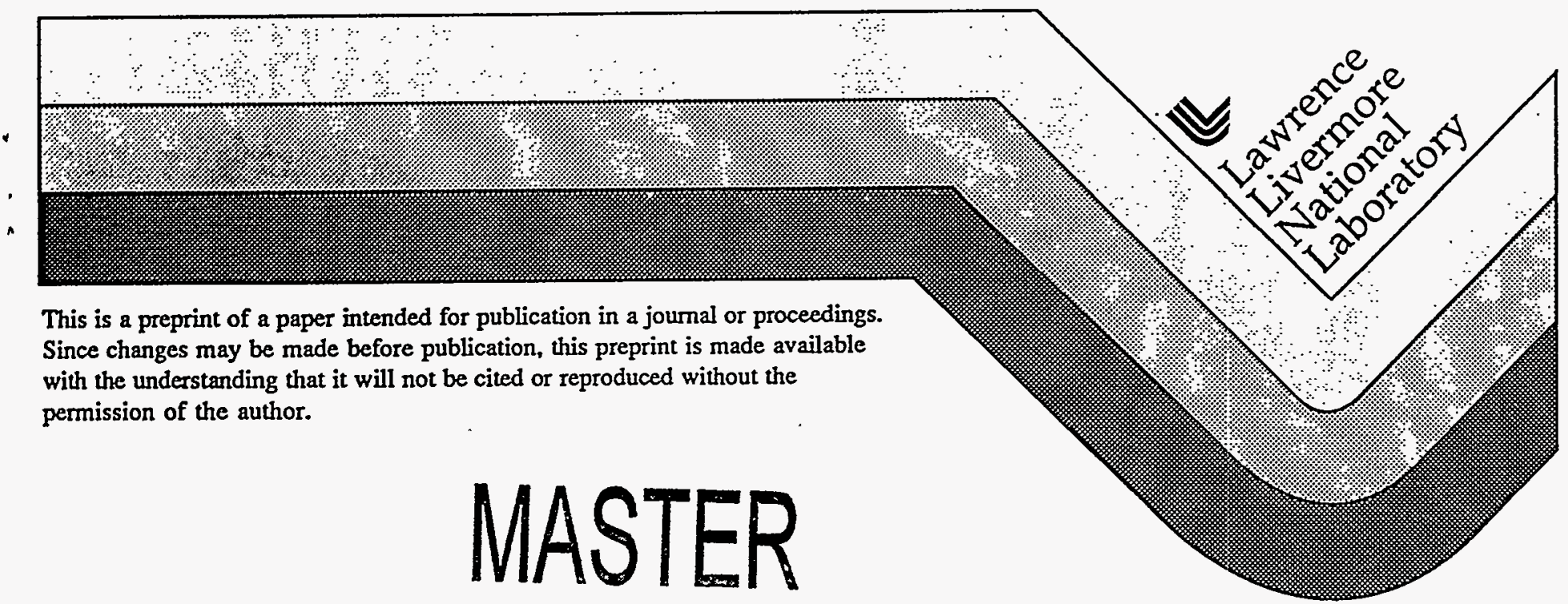




\section{DISCLAIMIER}

Portions of this document may be illegible in electronic image products. Images are produced from the best available original document. 


\title{
A COMPARISON OF THE ELECTROCHEMICAL BEHAVIOR OF CARBON AEROGELS AND ACTIVATED CARBON FIBER CLOTHS
}

\author{
T. D. TRAN, C. T. ALVISO, S. S. HULSEY, J. K. NIELSEN, AND R. W. PEKALA \\ Chemistry \& Materials Science Department, \\ Lawrence Livermore National Laboratory, Livermore, CA 94550
}

\section{ABSTRACT}

The electrochemical capacitative behavior of carbon aerogels and selected commercial carbon fiber cloths was studied in $5 \mathrm{M}$ potassium hydroxide, $3 \mathrm{M}$ sulfuric acid, and $0.5 \mathrm{M}$ tetraethylammonium tetrafluoroborate/propylene carbonate electrolytes. The resorcinolformaldehyde based carbon aerogels with a range of density $(0.2-0.85 \mathrm{~g} / \mathrm{cc})$ have open-cell structures with ultrafine pore sizes $(\sim 5-50 \mathrm{~nm})$, high surface area $\left(400-700 \mathrm{~m}^{2} / \mathrm{g}\right)$, and a solid matrix composed of interconnected particles or fibers with characteristic diameters of $10 \mathrm{~nm}$. The commercial fiber cloths in the density range $0.2-0.4 \mathrm{~g} / \mathrm{cc}$ have high surface areas $(1000-2500$ $\mathrm{m}^{2} / \mathrm{g}$ ). The volumetric capacitances of high-density aerogels are shown to be comparable to or exceeding those obtained from activated carbon fibers. The electrochemical behavior of these types of materials in various electrolytes is compared and related to their physical properties.

\section{INTRODUCTION}

Carbons materials with high surface areas are attractive for use in electrochemical double-layer capacitors. These include activated carbons, mesophase microbeads, carbon fibers, and aerogels. Many of these materials have been demonstrated to have double-layer capacitance as high as $150 \mathrm{~F} / \mathrm{g}$ [1]. Typically, high-surface-area carbons tend to have low densities (i.e., 0.1$0.2 \mathrm{~m}^{2} / \mathrm{g}$ ). Hence, on a volume basis, their (volumetric) capacitance densities might be low. Practical supercapacitors require both high gravimetric as well as high volumetric energy densities.

In aerocapacitor applications using $5 \mathrm{M} \mathrm{KOH}[2,3]$, carbon aerogels are used that have large specific as well as volumetric capacitances. This is because high-surface-area carbon aerogels can be prepared at high density (approaching $1 \mathrm{~g} / \mathrm{cc}$ ). We have discussed the synthesis and characteristics of these aerogels elsewhere [2,4]. The carbon aerogels have a monolithic structure consisting of interconnected particles or fibers with characteristic diameters about 10 $\mathrm{nm}$. The structure is porous and open with micropore sizes in the range of $25 \mathrm{~nm}$ or less. In this work, we compared the physical properties and capacitance of these types of carbon aerogels to selected commercial carbon fiber cloths which have desirable properties for electrochemical double-layer application such as high surface areas (e.g., 1500-2500 $\mathrm{m}^{2} / \mathrm{g}$ ). The study was done in potassium hydroxide, sulfuric acid and tetraethylammonium tetrafluoroborate/propylene carbonate electrolytes. These three types of electrolytes are most commonly used in laboratory and commercial cells.

\section{EXPERIMENTAL}

The preparation of resorcinol-formaldehyde (RF) aerogels and their carbonized derivatives has been described elsewhere [5]. Briefly, resorcinol (1,3 dihydroxybenzene) and formaldehyde were mixed in a 1:2 molar ratio, respectively. Deionized/distilled water was added as the diluent and sodium carbonate as the base catalyst. After stirring to form a homogeneous solution, the mixture was poured into glass vials, sealed, and cured at elevated temperature (50$85^{\circ} \mathrm{C}$ ). Upon completion of the cure cycle, the crosslinked gels were exchanged with acetone and subsequently dried from supercritical carbon dioxide $\left(\mathrm{Tc}=31^{\circ} \mathrm{C} ; \mathrm{Pc}=7.4 \mathrm{MPa}\right)$. This procedure resulted in the formation of monolithic RF aerogels which were subsequently pyrolyzed (600$1050^{\circ} \mathrm{C}$ ) in flowing nitrogen to form carbon aerogels.

Commercial carbon fiber cloths were obtained from American Kynol Inc. (NY) and Spectra Corp. (MA). Three types of American Kynol woven fabrics, ACC505-10, ACC507-15

$$
\text { DISTAIBUTION OF THIS DOCUMENT IS UNLLMTED SLC }
$$


and ACC5092-25 have surface areas of 1000,1500 and $2500 \mathrm{~m}^{2} / \mathrm{g}$, respectively. Spectra Corp. woven fiber cloth no. 2225 was reported to have BET surface area of $2500 \mathrm{~m}^{2} / \mathrm{g}$. Their physical properties are summarized in Table 1 . The carbon fiber cloths are used directly without additional treatment.

Electrochemical studies were performed using a 64-channel Maccor battery tester. Experiments were done using circular (4.5cm-diameter) Teflon cells. The two identical $1.5 \mathrm{~cm}$ diameter carbon electrodes were separated by 2 pieces of Whatman fiberglass filter papers (934AH). Nickel foils were used as current collectors in sodium hydroxide ( $5 \mathrm{M} \mathrm{KOH})$ electrolytes while tantalum exmets were used in sulfuric acids $\left(3 \mathrm{M} \mathrm{H}_{2} \mathrm{SO}_{4}\right)$. Aluminum foils were used as current collectors in cells with organic electrolytes $(0.5 \mathrm{M}$ tetraethylammonium tetrafluoroborate $\left(\mathrm{Et}_{4} \mathrm{NBF}_{4}\right.$, Aldrich) in propylene carbonate). The whole assembly is sandwiched between 2 teflon plates and held together by $0.6 \mathrm{~cm}$-diameter Teflon screws. Electrolyte filling was accomplished via three successive evacuation ( $2 \mathrm{psi})$ and pressurization ( $24.5 \mathrm{psi})$ stages in approximately 1 hour. The operating voltages for the aqueous and organic cells are $1 \mathrm{~V}$ and $3 \mathrm{~V}$ per cell, respectively. The assembly and testing of aqueous cells were carried out under ambient conditions. The experiments with organic electrolyte were performed in a dry argon-atmosphere glove box ( $<15 \mathrm{ppm}$ water) at $20 \pm 2^{\circ} \mathrm{C}$. The capacitance was determined from the discharge capacity $(\mathrm{C}=\mathrm{Q} / \mathrm{V})$ of cells fully charged at a constant current to the indicated voltage limit. The total dry weight and volume of the two carbon electrodes were used in the capacitance density calculations. A variety of characterization techniques were used to analyze the carbon aerogels. The BET surface area and pore size distribution were obtained using a multi-point $\mathrm{N}_{2}$ gas adsorption technique (Micromeritics ASAP 2000). The electrode morphology was examined by scanning and transmission electron microscopy.

\section{RESULTS AND DISCUSSION}

The structure and properties of RF-derived carbon aerogels are largely controlled by the [Resorcinol]/[Catalyst] (R/C) ratio of the starting solution. Details on the synthesis of tailored aerogel structures have been reported $[5,6]$. Carbon aerogels synthesized at $R / C$ ratio of 200 tend to have surface areas in the range of $\sim 600 \mathrm{~m}^{2} / \mathrm{g}$ with spherical particles and pore size about 5-25 $\mathrm{nm}$. The specific and volumetric surface areas of RF aerogels and carbon cloths as a function of density are shown in Figure 1. At the same R/C ratio, the specific surface area of these carbon aerogels is independent of the bulk density. However, in terms of the volumetric basis, aerogel BET surface areas tend to increase with increasing density. The BET surface areas and superficial densities of the carbon fiber sheets were also obtained and are shown in Table 1 .

Table 1. Properties of carbon aerogels and woven carbon fibers

\begin{tabular}{|l|l|l|c|c|c|c|c|}
\hline Carbon & Source & Description & $\begin{array}{c}\text { BET area } \\
\text { (reported) } \\
\mathrm{m}^{2} / \mathrm{g}\end{array}$ & $\begin{array}{c}\mathrm{BET} \text { area } \\
\text { (measured) } \\
\mathrm{m}^{2} / \mathrm{g}\end{array}$ & $\begin{array}{c}\text { Pore } \\
\text { size, } \AA\end{array}$ & $\begin{array}{c}\text { Density } \\
\mathrm{g} / \mathrm{cm}^{3}\end{array}$ & $\begin{array}{c}\text { Thickness } \\
\mathrm{mm}\end{array}$ \\
\hline aerogels & LLNL & $\mathrm{R} 100 \mathrm{R} / \mathrm{C}=200$ & & 617 & 260 & 0.16 & 1.0 \\
\hline aerogels & LLNL & $\mathrm{R} 200 \mathrm{R} / \mathrm{C}=200$ & & 660 & 140 & 0.31 & 1.0 \\
\hline aerogels & LLNL & $\mathrm{R} 300 \mathrm{R} / \mathrm{C}=200$ & & 700 & 95 & 0.44 & 1.0 \\
\hline aerogels & LLNL & $\mathrm{R} 400 \mathrm{R} / \mathrm{C}=200$ & & 666 & 65 & 0.58 & 1.0 \\
\hline aerogels & LLNL & $\mathrm{R} 500 \mathrm{R} / \mathrm{C}=200$ & & 580 & 50 & 0.83 & 1.0 \\
\hline $\begin{array}{l}\text { woven } \\
\text { fibers }\end{array}$ & $\begin{array}{l}\text { American } \\
\text { Kynol }\end{array}$ & ACC505-10 & 1000 & 1170 & $<30$ & 0.42 & 0.279 \\
\hline $\begin{array}{l}\text { woven } \\
\text { fibers }\end{array}$ & $\begin{array}{l}\text { American } \\
\text { Kynol }\end{array}$ & ACC507-15 & 1500 & 1670 & $<30$ & 0.31 & 0.330 \\
\hline $\begin{array}{l}\text { woven } \\
\text { fibers }\end{array}$ & $\begin{array}{l}\text { American } \\
\text { Kynol }\end{array}$ & ACC5092-25 & 2500 & 1690 & $<30$ & 0.27 & 0.480 \\
\hline $\begin{array}{l}\text { woven } \\
\text { fibers }\end{array}$ & $\begin{array}{l}\text { Spectra } \\
\text { Corp. }\end{array}$ & $\# 2225$ & 2500 & - & - & 0.23 & 0.50 \\
\hline
\end{tabular}


A lower BET value was measured for the ACC5092-25 sample. While the specific BET areas of these commercial cloths are significantly larger than those of aerogels, the volumetric surface areas of these materials are comparable to those of the latter. A maximum value of $500 \mathrm{~m}^{2}$ per cc was determined for the studied materials.

The pore size distribution of aerogels and American Kynol ACC507-15 electrodes were obtained from multipoint $\mathrm{N}_{2}$ gas adsorption experiments. The pore volume distribution in aerogel materials resembles a Gaussian behavior. TEM observations showed an open microstructure consisting of uniform pores of the similar dimension. Table I shows the average pore size for various types of aerogels prepared at different $\mathrm{R} / \mathrm{C}$ ratios. On the other hand, the distribution curve for the commercial fabric shows the preponderance of micropores less than $30 \AA$. This is consistent with the high surface areas associated with these carbon cloths.

The specific capacitance ( $\mathrm{F} / \mathrm{g}$ ) and volumetric capacitance densities (F/cc) for aerogels and.carbon fabrics in $5 \mathrm{M} \mathrm{KOH}$ are plotted in Figure 2. A maximum specific capacitance value of $40 \mathrm{~F} / \mathrm{g}$ was obtained for ACC507-15 which has a surface area of $1670 \mathrm{~m}^{2} / \mathrm{g}$. A comparable number was determined for ACC509-25, consistent with the measured BET surface areas. The specific capacity of the high-density aerogels is comparable to those of fibers (i.e., $35 \mathrm{~F} / \mathrm{g}$ ) despite a three-fold reduction in measured BET area. This may be attributed to larger pore sizes and accessible microstructure associated with the aerogel matrix.

When the volumetric capacitances of the carbon materials are compared, the values for aerogels exceeds those of activated fibers, providing 10-20\% more capacity per cc of electrode volume. While the data for $\mathrm{R} / \mathrm{C}=200$ aerogels in this study was limited to samples with densities up to $0.8 \mathrm{~g} / \mathrm{cc}$, we have presented elsewhere a linear increase in volumetric capacitance with density for aerogels with different $\mathrm{R} / \mathrm{C}$ ratios [2]. In this case, a maximum was observed near $1 \mathrm{~g} / \mathrm{cc}$. It is possible that a higher performance R/C200 aerogels could be achieved from samples with high densities $(>0.8 \mathrm{~g} / \mathrm{cc}$ ). The drop-off.in capacitance for high-densities $(>1 \mathrm{~g} / \mathrm{cc}$ ) aerogels was attributed to small pores and/or tortuous pore structure which perhaps interfere with the double-layer formation.

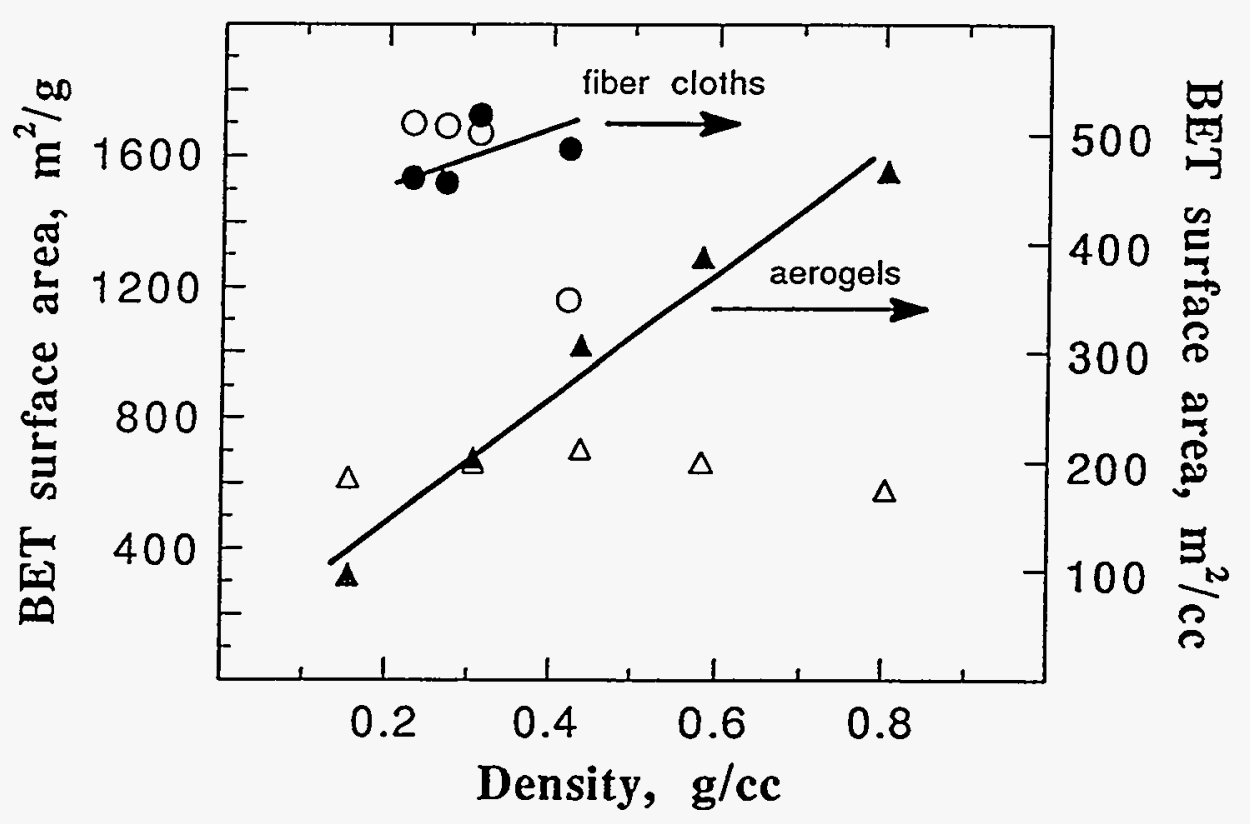

Figure 1. Plot of specific and volumetric surface areas as functions of density. 


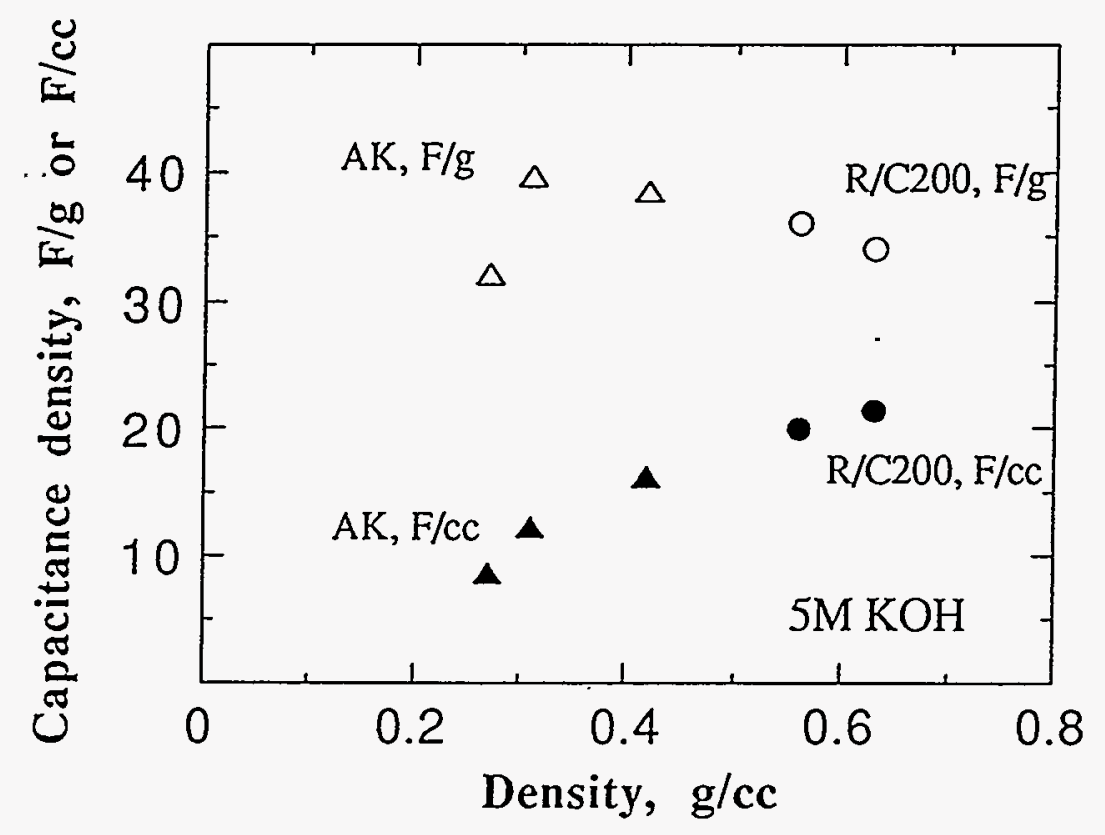

Figure 2. Plot of capacitance versus density for areogels $(R / C=200)$ and fibers $(A K)$ in $5 \mathrm{MKOH}$.

Figure 3 shows the specific capacitance $(\mathrm{F} / \mathrm{g})$ and volumetric capacitance densities $(\mathrm{F} / \mathrm{cc})$ as a function of electrode bulk density for carbon fabrics and aerogels in $3 \mathrm{M} \mathrm{H}_{2} \mathrm{SO}_{4}$. Similar to the results for $5 \mathrm{M} \mathrm{KOH}$, the volumetric capacitances of carbon aerogels are slightly larger than those for carbon fibers. The specific capacitance values in $3 \mathrm{M} \mathrm{H}_{2} \mathrm{SO}_{4}$ electrolytes are about $30 \%$ less than those obtained in $5 \mathrm{M} \mathrm{KOH}$. The interaction of a stronger adsorbate, $\mathrm{SO}_{4}{ }^{2-}$ anion, appears to affect the carbon capacity.

A comparison of the performance of aerogels and fiber sheets in $0.5 \mathrm{M} \mathrm{Et}_{4} \mathrm{NBF}_{4}$ is shown in Figure 4. The capacity of carbon electrodes in organic electrolyte was about half those obtained in aqueous electrolytes. Cells with an organic electrolyte under these conditions would represent approximately a four-fold increase in specific energy densities $\left(1 / 2 \mathrm{CV}^{2}\right)$ compared to those of the latter. The volumetric capacitances of both aerogels and carbon fibers were comparable at about $5 \mathrm{~F} / \mathrm{cc}$. It is of interest to note here that a maximum in capacitance could be observed for both types of materials. The high-density aerogels $(0.83 \mathrm{~g} / \mathrm{cc})$ showed a decrease in capacitance. A similar trend was observed with the fiber sheets but the maximum was present near $0.3 \mathrm{~g} / \mathrm{cc}$. In contrast, the presence of a maximum in the volumetric capacitance was not apparent in the data for aqueous electrolytes shown in Figures 3 and 4. The size of the ions plays an important role in the formation of the electrochemical double layer in the pore. Further studies will investigate this issue.

\section{ACKNOWLEDGMENT}

The authors would like to thank Dr. Gerald Flemming (Spectra Corp.) and American Kynol Corp. for providing the woven carbon fiber fabrics. This work was performed under the auspices of the U.S. Department of Energy by Lawrence Livermore National Laboratory under Contract No. W-7405-ENG-48 with financial support from the Office of Basic Energy Sciences Division of Advanced Energy Projects. 

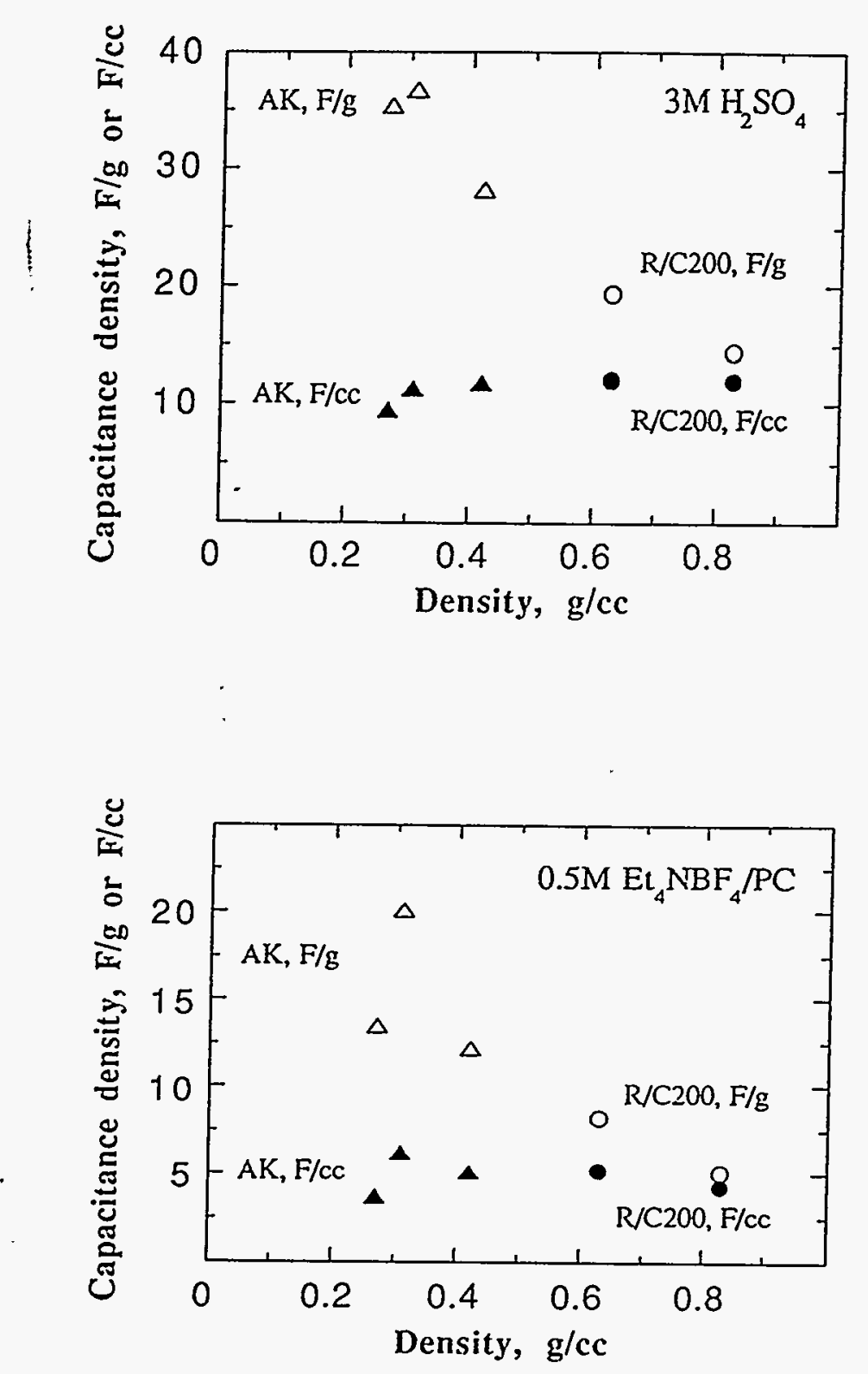

Figure 3.

Plot of capacitance versus density for areogels $(\mathrm{R} / \mathrm{C}=200)$ and fibers $(\mathrm{AK})$ in $3 \mathrm{M} \mathrm{H}_{2} \mathrm{SO}_{4}$.
Figure 4.

Plot of capacitance versus. density for areogels $(\mathrm{R} / \mathrm{C}=200)$ and fibers $(\mathrm{AK})$ in $0.5 \mathrm{M} \mathrm{Et}_{4} \mathrm{NBF}_{4} / \mathrm{PC}$.

\section{REFERENCES}

1. See papers at the Fall meeting of the Electrochemical Society, Chicago, IL, October 8-13 (1995).

2. S. T. Mayer, R. W. Pekala, and J. L. Kaschmitter, J. Electrochem. Soc. 140, p. 446 (1993).

3. M. J. Isaacson, J. L. Kaschmitter, B. J. Kraemer, T. J. Laramore, S. T. Mayer, R. W. Pekala, L. C. Josephs and D. Gregory, Fifth International Seminar on Double Layer Capacitors, Boca Raton, FL, December 4-6, 1995

4. R. W. Pekala, S. T. Mayer, J. F. Poco and J. L. Kaschmitter in Novel Forms of Carbon I, edited by C. L. Renschler, D. M. Cox J. J. Pouch, and Y. Achiba (MRS Sym. Proc. 349, p.

5. R. W. Pekala, and C. T. Alviso in Novel Forms of Carbon, edited by C. L. Renschler, J. J. Pouch, and D. M. Cox (MRS Sym. Proc. 270, p. 3, 1992)

6. R. W. Pekala and D. W. Schaefer, Macromolecules 26(20), p. 5487.(1993). 


\section{DISCLAIMER}

This report was prepared as an account of work sponsored by an agency of the United States Government. Neither the United States Government nor any agency thereof, nor any of their employees, make any warranty, express or implied, or assumes any legal liability or responsibility for the accuracy, completeness, or usefulness of any information, apparatus, product, or process disclosed, or represents that its use would not infringe privately owned rights. Reference herein to any specific commercial product, process, or service by trade name, trademark, manufacturer, or otherwise does not necessarily constitute or imply its endorsement, recommendation, or favoring by the United States Government or any agency thereof. The views and opinions of authors expressed herein do not necessarily state or reflect those of the United States Government or any agency thereof. 